\title{
Antibacterial and Antioxidant Xanthones and Benzophenone from Garcinia smeathmannii
}

Hugues Fouotsa ${ }^{1,2}$, Alain Meli Lannang ${ }^{2,3}$, Jean Paul Dzoyem ${ }^{4}$, Simplice J. N. Tatsimo ${ }^{3}$, Beate Neumann ${ }^{5}$, Celine Djama Mbazoa ${ }^{1}$, Andrianambinina Andriamarolahy Razakarivony ${ }^{2}$, Augustin Ephrem Nkengfack ${ }^{1}$, Jacobus N. Eloff ${ }^{6}$, Norbert Sewald ${ }^{2}$

\footnotetext{
${ }^{1}$ Department of Organic Chemistry, Faculty of Science, University of Yaoundé I, Yaoundé, Cameroon ${ }^{2}$ Department of Chemistry, Organic and Bioorganic Chemistry, Bielefeld University, Bielefeld, Germany ${ }^{3}$ Department of Chemistry, Higher Teachers' Training College, University of Maroua, Maroua, Cameroon ${ }^{4}$ Department of Biochemistry, Faculty of Science, University of Dschang, Dschang, Cameroon ${ }^{5}$ Department of Chemistry, Inorganic and Structural Chemistry, Bielefeld University, Bielefeld, Germany ${ }^{6}$ Phytomedicine Programme, Department of Paraclinical Sciences, Faculty of Veterinary Science, University of Pretoria, Pretoria, South Africa
}

\author{
Correspondence \\ Dr. Alain Meli Lannang \\ Department of Chemistry, Higher Teachers' Training College, University of Maroua \\ P. O. Box 55
}

Maroua

Cameroon

Phone: +2376 77534830

Fax: +237242229116

Email: alainmeli@yahoo.com

\section{Abstract}

A new prenylated xanthone, 1,3,5,8-tetrahydroxy-2-(3-methybut-2-enyl)-4-(3,7dimethylocta-2,6-dienyl) xanthone (1), and a new benzophenone (2), together with four known xanthone derivatives, cheffouxanthone (3), smeathxanthone A (4), smeathxanthone $B(5)$, ananixanthone (6), and two pentacyclic triterpenes, epi-friedelinol (7) and friedelin (8), were isolated from the stem bark of Garcinia smeathmannii. The structures of the compounds were elucidated on the basis of 1D and 2D NMR experiments, and compound 2 was further characterized and confirmed by single X-ray analysis. Compounds 1,2 , and 3 exhibited the most prominent Garcinia activity against gram-positive Enterococcus faecalis with minimal inhibitory concentration values of 8,8 , and $2 \mu \mathrm{g} / \mathrm{mL}$, respectively, while compounds $1,3,4$, and 6 showed the capacity to scavenge free radicals.

\section{Key words}

Garcinia smeathmannii - Guttiferae - xanthone - benzophenone - antibacterial - antioxidant 


\section{Introduction}

Plants of the genus Garcinia (Guttiferae) have been extensively investigated from both phytochemical and biological points of view, and they are well known as a rich source of natural xanthones [1], biflavonoids [2], benzophenones [2] as well as triterpenoids [3].

Phenolic constituents from Garcinia species have been reported to display antibacterial [4], [5], [6], cytotoxic [7], prooxidant [8] as well as anticancer activities [9] and to inhibit $\alpha$ glucosidase [10] and HIV [11]. Garcinia smeathmannii Oliver (syn. Garcinia barteri) is widely distributed in the lowland tropical rainforests of Western and Central Africa [12], [13], [14]. G. smeathmanii is used as an antidote for many poisons and for the treatment of ophthalmia [14]. Previously, xanthones, benzophenones, and triterpenes from the root and stem bark of G. smeathmannii were reported by our research group [15], [16], [17].

In the course of our continuing phytochemical investigation on Garcinia plants found in Cameroon, phytochemical studies of the stem bark of G. smeathmannii and their biological activities were carried out. We report herein the isolation and characterization of one new xanthone and one new benzophenone, together with four known xanthones and two pentacyclic triterpenes. We also report the antibacterial and antioxidant activities of the isolated compounds.

\section{Results and Discussion}

A phytochemical investigation of the methanol extract of $G$. smeathmannii led to the isolation of a new prenylated xanthone, 1,3,5,8-tetrahydroxy-2-(3-methybut-2-enyl)-4-(3,7dimethyloct-2,6-dienyl) xanthone (1), and a new benzophenone (2), along with four known xanthone derivatives, cheffouxanthone (3) [15], smeathxanthone A (4) [16], smeathxanthone B (5) [16], and ananixanthone (6) [18], and two pentacyclic triterpenes, epi-friedelinol (7) [19] and friedelin (8) [17]. Compounds 1, 2, 3, 4, and 6 were tested for their antibacterial and antioxidant activities. In addition, the known compounds 3, 4, 5, and 8 were previously isolated from the root and stem bark of G. smeathmannii [15], [16], [17], while compound 6 was reported in Garcinia paucinervis [18]. Compound 7 is reported in Garcinia species for the first time.

Compound 1 was obtained as a yellow powder, and its molecular formula was assigned to be $\mathrm{C}_{28} \mathrm{H}_{32} \mathrm{O}_{6}$ from its $\mathrm{HR}$-EI-MS and NMR data ([Table 1]), indicating thirteen double bond equivalents. The IR spectrum displayed hydroxyl $\left(3350 \mathrm{~cm}^{-1}\right)$, carbonyl $\left(1720 \mathrm{~cm}^{-1}\right)$, and aromatic $\left(1627,1617,1580 \mathrm{~cm}^{-1}\right)$ absorptions. The UV spectrum showed absorption characteristic for a tetrahydroxylated xanthone [20], [21]. The ${ }^{1} \mathrm{H}$ and ${ }^{13} \mathrm{C}$ NMR data ([Table 1]) of compounds 1 and 3 were similar. The difference was observed at position 2 where the proton signal at $\delta_{H} 6.38(\mathrm{~s})$ in compound 3 disappeared in compound 1 and by the presence of new signals at $\delta_{H} 5.23(\mathrm{t}, \mathrm{J}=7.3 \mathrm{~Hz}), 3.45(\mathrm{~d}, \mathrm{~J}=7.3 \mathrm{~Hz}), 1.66(\mathrm{~s})$, and $1.79(\mathrm{~s})$, characteristic of a prenyl group. This was confirmed by ${ }^{13} \mathrm{C}$ NMR spectra of compound 1 with five more signals at $\delta_{c} 22.0,122.7,132.7,25.8$, and 18.0. In the HMBC spectrum, the signal of the benzylic proton $\delta_{H} 3.68\left(\mathrm{H}-1^{\prime}\right)$ of the geranyl substituent showed cross-peaks with the 
Table $1{ }^{1} \mathrm{H}$ NMR $(500 \mathrm{MHz})$ and ${ }^{13} \mathrm{C}-\mathrm{NMR}(125 \mathrm{MHz})$ data of compound 1 in $\mathrm{d}_{6}$-acetone.

\begin{tabular}{|c|c|c|c|}
\hline No. & ${ }^{1} \mathrm{H}$ (multi.; $\mathrm{J}$ in $\mathrm{Hz}$ ) & ${ }^{13} \mathrm{C}$ & HMBC \\
\hline 1 & - & 158.8 & \\
\hline 2 & - & 111.6 & \\
\hline 3 & - & 162.3 & \\
\hline 4 & - & 107.7 & \\
\hline 5 & - & 138.1 & \\
\hline 6 & $7.31(\mathrm{~d} ; \mathrm{J}=8.8)$ & 124.6 & $138.1 ; 145.0 ; 154.2$ \\
\hline 7 & $6.62(\mathrm{~d} ; \mathrm{J}=8.8)$ & 109.9 & $108.3 ; 138.1 ; 154.2$ \\
\hline 8 & - & 154.2 & \\
\hline 9 & - & 186.0 & \\
\hline $4 a$ & - & 153.6 & \\
\hline $8 a$ & - & 108.3 & \\
\hline $9 a$ & - & 102.7 & \\
\hline $10 a$ & - & 145.0 & \\
\hline $1^{\prime}$ & $3.68(\mathrm{~d} ; \mathrm{J}=7.2)$ & 22.2 & $107.7 ; 122.8 ; 136.7 ; 153.6 ; 162.3$ \\
\hline $2^{\prime}$ & $5.31(\mathrm{t} ; \mathrm{J}=7.2)$ & 122.8 & $16.4 ; 22.2 ; 40.4$ \\
\hline $3^{\prime}$ & - & 136.7 & \\
\hline $4^{\prime}$ & $1.98(\mathrm{t} ; \mathrm{J}=7.0)$ & 40.4 & $16.4 ; 27.2 ; 122.8 ; 136.7$ \\
\hline $5^{\prime}$ & $2.05(\mathrm{~m})$ & 27.2 & $40.4 ; 124.6 ; 131.7$ \\
\hline $6^{\prime}$ & $5.04(\mathrm{~d} ; \mathrm{J}=7.2)$ & 124.9 & 17.6 \\
\hline $7^{\prime}$ & - & 131.7 & \\
\hline $8^{\prime}$ & $1.56(\mathrm{~s})$ & 25.7 & $17.6 ; 124.9 ; 131.7$ \\
\hline $9^{\prime}$ & $1.51(\mathrm{~s})$ & 17.6 & $25.7 ; 124.9 ; 131.7$ \\
\hline $10^{\prime}$ & $1.86(\mathrm{~s})$ & 16.4 & $40.4 ; 122.8 ; 136.7$ \\
\hline $1^{\prime \prime}$ & $3.45(\mathrm{~d} ; \mathrm{J}=7.3)$ & 22.0 & $111.6 ; 122.7 ; 132.7 ; 158.8 ; 162.3$ \\
\hline $2^{\prime \prime}$ & $5.23(\mathrm{~d} ; \mathrm{J}=7.3)$ & 122.7 & $18.0 ; 25.8$ \\
\hline $3^{\prime \prime}$ & - & 132.7 & \\
\hline $4^{\prime \prime}$ & $1.66(\mathrm{~s}, 3 \mathrm{H})$ & 25.8 & $18.0 ; 122.7 ; 132.7$ \\
\hline $5^{\prime \prime}$ & $1.79(\mathrm{~s}, 3 \mathrm{H})$ & 18.0 & $25.8 ; 122.7 ; 132.7$ \\
\hline 1-OH & $12.34(\mathrm{~s})$ & - & $102.7 ; 111.6 ; 158.8$ \\
\hline $3-\mathrm{OH}$ & - & - & - \\
\hline $5-\mathrm{OH}$ & - & - & - \\
\hline $8-\mathrm{OH}$ & $11.31(\mathrm{~s})$ & - & $108.3 ; 109.9 ; 154.2$ \\
\hline
\end{tabular}

carbon signals at $\delta_{\text {C }} 107.7$ (C-4), 153.6 (C-4a), 162.3 (C-3), 136.7 (C-3'), and 122.8 (C-2'), demonstrating the attachment of the geranyl group to $\mathrm{C}-4$. In addition, the proton of $\mathrm{H}-\mathrm{1}^{\prime \prime}$ $\left(\delta_{H} 3.45\right)$ showed a correlation with $C-1\left(\delta_{C} 158.8\right), C-2\left(\delta_{C} 111.6\right)$, and C-3 $\left(\delta_{C} 162.3\right)$, confirming that the prenyl group is linked to $\mathrm{C}-2$. The El mass spectrum of compound 1 showed a parent peak at $\mathrm{m} / \mathrm{z} 464$ and two fragment ions at $\mathrm{m} / \mathrm{z} 123(11 \%)$ and 69 (25\%), suggesting the presence of one geranyl and one prenyl substituent. In addition, the base peak at $\mathrm{m} / \mathrm{z} 285(100 \%)$ was a result of the loss of two neutral fragments, $\mathrm{C}_{4} \mathrm{H}_{7}$ for a prenyl 
<smiles>CC(F)=C[CH+]c1c(O)c(CC=C(C)CCC=C(C)F)c2oc3c(O)ccc(O)c3c(=O)c2c1O</smiles><smiles>CC(C)=CCC/C(C)=C/Cc1c(O)cc(O)c2c(=O)c3c(O)ccc(O)c3oc12</smiles><smiles>CC(C)=CCCC1(C)C=Cc2c(cc3oc4c(O)ccc(O)c4c(=O)c3c2O)O1</smiles><smiles>C[C@H]1[C@@H](O)CCC2[C@@]3(C)CC[C@]4(C)C5CC(C)(C)CC[C@]5(C)CC[C@]4(C)C3CC[C@]21C</smiles>

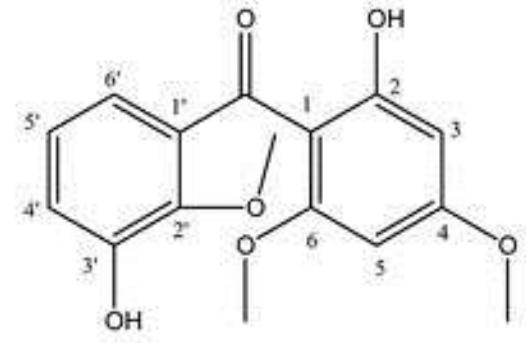

2<smiles>CC(C)=CCC/C(C)=C/Cc1c(O)cc2oc3c(O)ccc(O)c3c(=O)c2c1O</smiles><smiles>CC(C)=CCc1c2c(c3oc4c(O)cccc4c(=O)c3c1O)C=CC(C)(C)O2</smiles><smiles>C[C@H]1C(=O)CCC2[C@@]3(C)CC[C@]4(C)C5CC(C)(C)CC[C@]5(C)CC[C@]4(C)C3CC[C@]21C</smiles>

Fig. 1 Structures of the isolated compounds.

group and $\mathrm{C}_{9} \mathrm{H}_{15}$ for a geranyl group, with such a loss being characteristic for compounds having a prenyl group adjacent to hydroxyl groups [22]. Thus, compound 1 was characterized as 1,3,5,8-tetrahydroxy-2-(3-methybut-2-enyl)-4-(3,7-dimethylocta-2,6-dienyl) xanthone. 


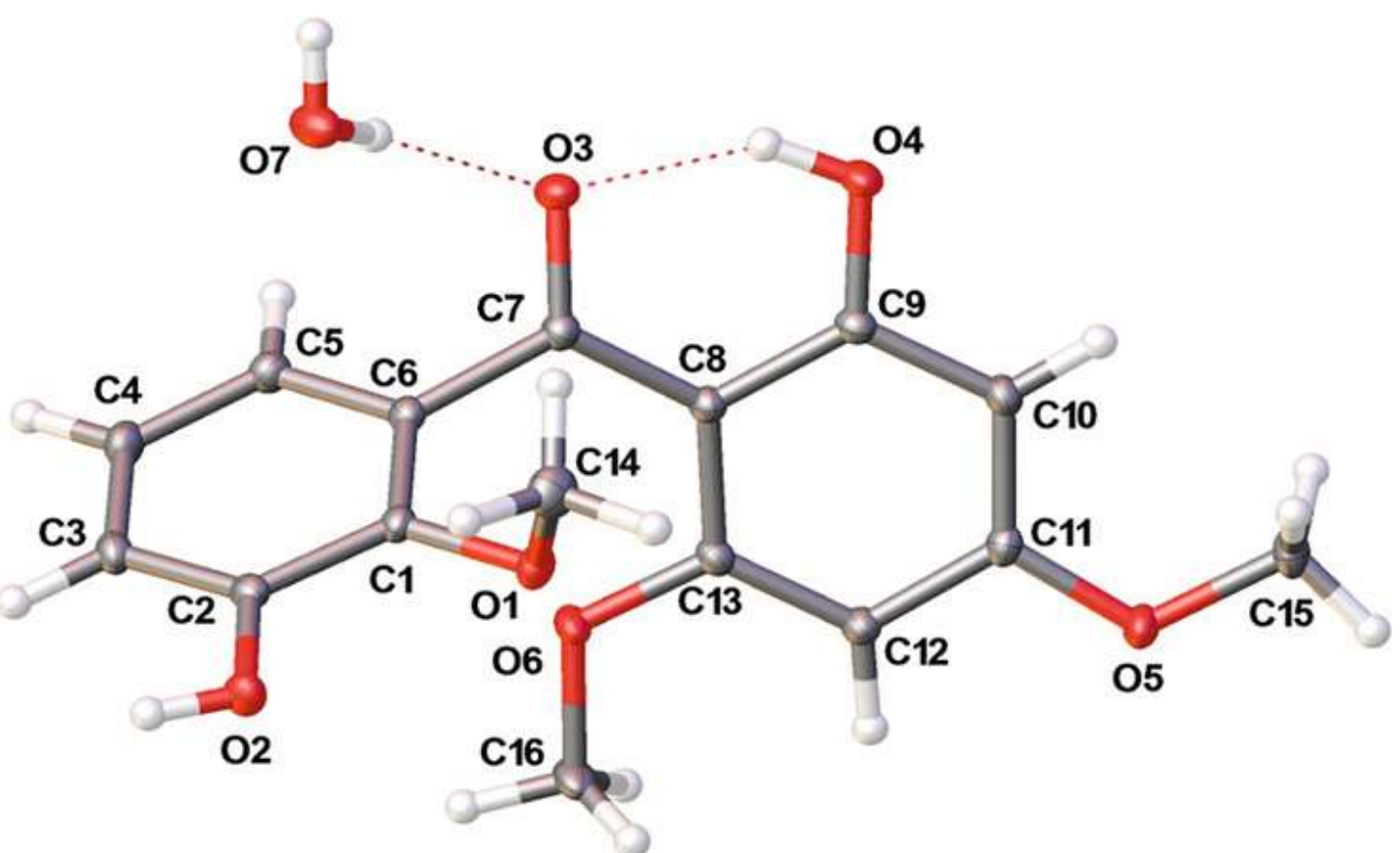

Fig. 2 ORTEP plot of 2. (Color figure available online only.)

Table $2{ }^{1} \mathrm{H}-(500 \mathrm{MHz}), \mathrm{HMBC}$, and ${ }^{13} \mathrm{C}-\mathrm{NMR}(125 \mathrm{MHz})$ data for compound 2 in $\mathrm{CD}_{3} \mathrm{OCD}_{3}$.

\begin{tabular}{|c|c|c|c|}
\hline No. & ${ }^{1} \mathrm{H}$ (multi.; J in $\mathrm{Hz}$ ) & ${ }^{13} \mathrm{C}$ & HMBC \\
\hline 1 & - & 107.1 & - \\
\hline 2 & - & 167.7 & - \\
\hline 3 & $6.13(\mathrm{~d} ; \mathrm{J}=2.3)$ & 94.3 & $91.7 ; 107.1 ; 167.7$ \\
\hline 4 & - & 168.1 & - \\
\hline 5 & $5.99(\mathrm{~d} ; \mathrm{J}=2.3)$ & 91.7 & 94.3; 107.1; 164.0; 168.1; 199.1 \\
\hline 6 & - & 164.0 & - \\
\hline $1^{\prime}$ & - & 138.6 & - \\
\hline $2^{\prime}$ & - & 144.7 & - \\
\hline $3^{\prime}$ & - & 150.4 & - \\
\hline $4^{\prime}$ & $6.96(\mathrm{dd} ; \mathrm{J}=7.1 ; 1.9)$ & 117.9 & $118.4 ; 144.7$ \\
\hline $5^{\prime}$ & $6.96(\mathrm{brt} ; \mathrm{J}=7.1)$ & 124.4 & $118.4 ; 144.7 ; 150.4 ; 138.6$ \\
\hline $6^{\prime}$ & $6.66(\mathrm{dd} ; \mathrm{J}=7.2 ; 1.9)$ & 118.4 & $117.9 ; 138.6 ; 144.7 ; 150.4 ; 199.1$ \\
\hline 2'-OMe & $3.66(\mathrm{~s})$ & 61.4 & 143.9 \\
\hline 4-OMe & $3.87(\mathrm{~s})$ & 56.0 & 168.1 \\
\hline 6-OMe & $3.44(\mathrm{~s})$ & 56.1 & 164.0 \\
\hline $2-\mathrm{OH}$ & $13.25(\mathrm{~s})$ & - & $94.3 ; 107.1 ; 167.7$ \\
\hline $3^{\prime}-\mathrm{OH}$ & $8.22(\mathrm{~s})$ & - & - \\
\hline $\mathrm{O}=\mathrm{C}$ & - & 199.1 & - \\
\hline
\end{tabular}


Compound 2 was obtained as a yellow crystal, m. p. $87-88^{\circ} \mathrm{C}$, and its molecular formula was assigned to be $\mathrm{C}_{16} \mathrm{H}_{16} \mathrm{O}_{6}$ from its HR-ESI-MS data. The UV and IR are characteristic for an oxygenated benzophenone [23]. The ${ }^{1} \mathrm{H}$ and ${ }^{13} \mathrm{C}$ NMR data of 2 ([Table 2]) were almost identical to those of 3',6-dihydroxy-2,4,4'-trimethoxybenzophenone isolated from Garcinia mangostana by Nilar et al. [23]. Its structure was solved by X-ray crystallography ([Fig. 2]) as 2,3'-dihydroxy-2',4,6-trimethoxybenzophenone ([Fig. 1]).

Results of the antibacterial activity of the compounds are shown in [Table 3]. Apart from compound 2, all the tested compounds showed significant to moderate activity against at least three of the six bacterial strains used. Compounds 1, 2, and 3 exhibited the most prominent antibacterial activity against gram-positive Enterococcus faecalis with MIC values of 8,8 , and $2 \mu \mathrm{g} / \mathrm{mL}$, respectively. Although no clear-cut structure-activity relationship could be derived, some basic activity trends could be observed from the comparison of the chemical structures of the compounds and their different activities. Compound 2 was the least active one against all the bacterial strains used with minimal inhibitory concentration (MIC) values greater than $256 \mu \mathrm{g} / \mathrm{mL}$, except against Staphylococcus aureus (MIC $128 \mu \mathrm{g} / \mathrm{mL}$ ). Among the tested samples, compound 2 appears to be a unique nonprenylated compound. Therefore, the absence of the lipophilic prenyl group in the xanthonic scaffold is probably the reason for the loss of this activity for compound 2. Many naturally occurring xanthones and their prenylated derivatives have been found to exhibit significant biological and pharmacological properties, such as antimicrobial and antitumor activities, and it can be inferred that the presence of prenyl groups can be associated with an improvement of potency and selectivity for some of these properties [24].

Table 3 Antibacterial activity of compounds $1-4$ and 6 (MIC in $\mu \mathrm{g} / \mathrm{mL}$ ).

\begin{tabular}{|c|c|c|c|c|c|c|}
\hline \multirow{2}{*}{ Compounds } & \multicolumn{5}{|c|}{ Microorganisms } \\
\cline { 2 - 7 } & S. aureus & E. faecalis & B. cereus & P. aeruginosa & E. coli & S. typhimurium \\
\hline \hline \multicolumn{5}{|c|}{} & \multicolumn{3}{|c|}{$-:>256 \mu \mathrm{g} / \mathrm{mL}$} \\
\hline \hline 1 & 64 & 8 & 256 & 16 & 32 & 64 \\
\hline \hline 2 & 128 & - & - & - & - & - \\
\hline \hline 3 & 64 & 8 & 32 & 128 & 64 & - \\
\hline \hline 4 & 32 & 16 & 64 & 256 & 32 & 256 \\
\hline \hline 6 & 32 & 2 & 64 & 64 & 128 & 256 \\
\hline \hline Gentamicin & 0.25 & 0.12 & 0.25 & 0.5 & 0.25 & 0.25 \\
\hline
\end{tabular}

The antioxidant properties of compounds $1-4$ and 6 were also studied, and the $\mathrm{IC}_{50}$ values are summarized in [Table 4]. All the tested compounds (except compound 2) showed the capacity to scavenge free radicals. I $C_{50}$ values ranged from 1.90 to $34.50 \mu \mathrm{g} / \mathrm{mL}$ in DPPH and ABTS assays, while the $\mathrm{FeSO}_{4} / \mathrm{g}$ equivalent varied from 46.17 to $1527.17 \mu \mathrm{mol} \mathrm{FeSO}_{4} / \mathrm{g}$ in the FRAP method. Compounds 3 and 4 showed the most potent antioxidant capacity, while compound 2 showed the lowest activity with an $\mathrm{IC}_{50}$ value greater than $100 \mu \mathrm{g} / \mathrm{mL}$. Considering that antioxidant activity is generally accepted to depend on the structure and substitution pattern of hydroxyl groups, we found a correlation between the radical scavenging activity and the number of free hydroxyl groups in the xanthone scaffold [25]. 
Some of the xanthones presented herein are potential antioxidants and antimicrobials or possibly derivatives with improved activity, which could be of interest for further development of the compounds taking into account the growing health problems related to oxidative stress and antimicrobial resistance.

Table 4 Antioxidant activity of compounds 1-4 and 6.

\begin{tabular}{|c|c|c|c|}
\hline Compounds & $\mathrm{DPPH}, \mathrm{IC}_{50}(\mu \mathrm{g} / \mathrm{mL})$ & ABTS, $I C_{50}(\mu \mathrm{g} / \mathrm{mL})$ & FRAP [ $\mu \mathrm{g} \mathrm{Fe} \mathrm{(II)/g]}$ \\
\hline \multicolumn{4}{|c|}{ Nd: not determined } \\
\hline 1 & $4.10 \pm 1.64$ & $>100$ & $1527.17 \pm 21.46$ \\
\hline 2 & $>100$ & $>100$ & $46.80 \pm 11.92$ \\
\hline 3 & $2.94 \pm 0.73$ & $1.90 \pm 0.03$ & $960.83 \pm 31.58$ \\
\hline 4 & $3.16 \pm 0.28$ & $1.92 \pm 0.06$ & $996.93 \pm 21.01$ \\
\hline 6 & $34.50 \pm 2.23$ & $5.63 \pm 0.65$ & $221.84 \pm 25.43$ \\
\hline Trolox & $5.36 \pm 0.10$ & $3.71 \pm 0.21$ & $\mathrm{Nd}$ \\
\hline Ascorbic acid & $2.80 \pm 0.03$ & $2.61 \pm 0.08$ & $\mathrm{Nd}$ \\
\hline
\end{tabular}

\section{Material and Methods}

\section{General}

Melting points were determined on a Büchi-540 melting point apparatus. IR spectra were determined on a Nicolet 380 Fourier Transform IR spectrometer. UV spectra were determined on a Spectronic Unicam spectrophotometer. The ${ }^{1} \mathrm{H},{ }^{13} \mathrm{C}$, and DEPT NMR spectra as well as two-dimensional experiments (COSY, NOESY, HMQC, and HMBC using pulsed field gradients) were recorded on a Bruker DRX 500 FT-NMR spectrometer, operating at $500 \mathrm{MHz}$ $\left({ }^{1} \mathrm{H}\right)$ and $125 \mathrm{MHz}\left({ }^{13} \mathrm{C}\right)$ and a Bruker Avance $600 \mathrm{FT}-\mathrm{NMR}$ spectrometer, operating at $600 \mathrm{MHz}\left({ }^{1} \mathrm{H}\right)$ and $150 \mathrm{MHz}\left({ }^{13} \mathrm{C}\right)$ in $\mathrm{CDCl}_{3}, \mathrm{~d}_{6}$-acetone, or $\mathrm{d}_{6}$-DMSO with TMS as the internal standard.

El mass spectra and accurate mass spectra were recorded with an LC linear ion trap instrument (Esquire 3000) using electrospray ionization in the negative or positive mode and a sector field mass spectrometer (Autospec X). Vacuum liquid chromatography (VLC) was carried out using Merck silica gel $60 \mathrm{~F}_{254}$ (230-400 mesh), column chromatography using Si Gel 60 (230-400 mesh, 70-230 mesh), and TLC analysis was performed on silica gel (Merck silica gel 60 with fluorescent indicator $U_{254}, 0.20 \mathrm{~mm}, 20 \times 20 \mathrm{~cm}$ ) with different mixtures of petrol ether, cyclohexane, dichloromethane, ethyl acetate, acetone and methanol as eluents; spots were visualized under UV lamps ( $254 \mathrm{~nm}$ and $365 \mathrm{~nm}$ ) or by $\mathrm{MeOH}-\mathrm{H}_{2} \mathrm{SO}_{4}$ reagent. Solvent evaporation was done using a rotavapor (laborota 4000; Heidolph). 


\section{Plant material}

The stem bark of $G$. smeathmannii was collected from Cheffou-Baham, Western Province, Cameroon in April 2010 and was identified by Victor Nana of the Cameroon National Herbarium (CNH), Yaoundé, where a voucher specimen ( 35 169/HNC) has been deposited.

\section{Extraction and isolation}

The air-dried, powdered stem bark of G. smeathmannii $(2.5 \mathrm{~kg})$ was extracted at room temperature for three days using distilled methanol $(12 \mathrm{~L})$. The crude methanol extract $(207 \mathrm{~g})$ obtained was partitioned with petroleum ether ( $88 \mathrm{~g} ; 2.5 \mathrm{~L})$, dichloromethane (20.4 g; $1.5 \mathrm{~L})$, and ethyl acetate (32 g; $2 \mathrm{~L}$ ).

The petroleum ether fraction ( $80 \mathrm{~g}$ ) was subjected to flash column chromatography using silica gel (230-400 mesh; $800 \mathrm{~g})$ eluted with petroleum ether, petroleum ether-EtOAc $(9: 1)$, petroleum ether-EtOAc $(7.5: 2.5)$, petroleum ether-EtOAc $(1: 1)$, EtOAc and EtOAc-MeOH $(7.5: 2.5)$ to give five main fractions labeled A (27 g), B (22 g), C (14 g), D (17 g), and E (6.4 g), respectively.

Fraction A ( $25 \mathrm{~g})$ was then subjected to column chromatography $(5 \times 100 \mathrm{~cm})$ on silica gel ( $600 \mathrm{~g}, 230-400 \mathrm{mesh}$ ) and eluted by a petroleum ether-EtOAc mixture of increasing polarity $(20: 1-3: 1)$. A total of 90 fractions of ca. $300 \mathrm{~mL}$ each were collected, concentrated and combined on the basis of TLC to give five subfractions indexed A1 to A4. Subfraction A2 $(2.3 \mathrm{~g})$ was subjected to column chromatography $(4 \times 30 \mathrm{~cm})$ on silica gel $(30 \mathrm{~g}, 70-230$ mesh) and eluted with petroleum ether-EtOAc (19:1) to give epi-friedelinol $(7,10 \mathrm{mg}$, $\geq 99 \%$ purity) and friedelin ( $8,25 \mathrm{mg}, \geq 99 \%$ purity). The subfraction A3 (1.9 g) was further subjected to column chromatography $(4 \times 30 \mathrm{~cm})$ on silica gel $(25 \mathrm{~g}, 70-230$ mesh) and eluted with petroleum ether-EtOAc ( $18: 2$ ) to yield compound 1 ( $8 \mathrm{mg}, \geq 98 \%$ purity). The subfraction A4 $(19.2 \mathrm{~g})$, after column chromatography $(5 \times 50 \mathrm{~cm})$ on silica gel $(350 \mathrm{~g}, 70-$ 230 mesh), yielded a mixture of polyprenylated benzophenones.

Fraction B ( $20 \mathrm{~g})$ was also subjected to column chromatography $(5 \times 100 \mathrm{~cm})$ on silica gel $(600 \mathrm{~g}, 230-400 \mathrm{mesh})$ and eluted with a petroleum ether-EtOAc mixture of increasing polarity $(20: 1-3: 1)$. Fifty fractions of ca. $300 \mathrm{~mL}$ each were collected and regrouped into three subfractions, B1 to B3, on the basis of their TLC profile. Subfraction B1 (1.8 g) was subjected to column chromatography $(4 \times 30 \mathrm{~cm})$ on silica gel $(20.0 \mathrm{~g}, 70-230 \mathrm{mesh})$ and eluted with a mixture of petroleum ether-EtOAc $(17: 3)$ to give compound $5(5.0 \mathrm{mg}, \geq 99 \%$ purity). Subfraction B2 $(8.0 \mathrm{~g})$ was subjected to column chromatography $(4 \times 30 \mathrm{~cm})$ on silica gel ( $20 \mathrm{~g}, 70-230$ mesh) and eluted with a mixture of petroleum ether-EtOAc $(13: 7)$ to yield compounds 6 ( $25.0 \mathrm{mg}, \geq 97 \%$ purity) and 3 ( $18.5 \mathrm{mg}, \geq 98 \%$ purity). Subfraction B3 ( $2.6 \mathrm{~g})$ was also subjected to column chromatography $(4 \times 30 \mathrm{~cm})$ on silica gel $(30 \mathrm{~g}, 70-230$ mesh) and eluted with a mixture of petroleum ether-EtOAc $(12: 8)$ to afford compounds 4 (15.0 $\mathrm{mg}, \geq 98 \%$ purity) and 2 ( $22.5 \mathrm{mg}, \geq 98 \%$ purity).

1,3,5,8-Tetrahydroxy-2-(3-methybut-2-enyl)-4-(3,7-dimethylocta-2,6-dienyl)xanthone (1): yellow powder, m.p. $172-173^{\circ} \mathrm{C}$; UV (MeOH): $\lambda_{\max }(\log \varepsilon)=283$ (4.6), 325 (4.2), 350 (4.3) 400 (3.8) nm; IR (KBr pellet): $v=2919,2851,1627,1617,1580,1485,1463,1314,1217$, 
1176, 1099, 1007, 967, 830, 809, 719, 704, 618, $589 \mathrm{~cm}^{-1} ;{ }^{1} \mathrm{H}$ NMR and ${ }^{13} \mathrm{C}$ NMR ([Table 1]);

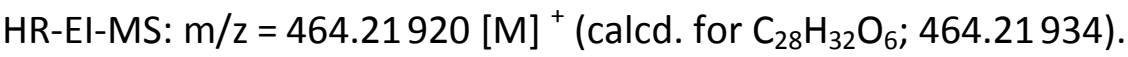

2,3'-Dihydroxy-2',4,6-trimethoxybenzophenone (2): yellow crystals, m. p. 87-88 ${ }^{\circ} \mathrm{C}$; UV $(\mathrm{MeOH}) \lambda_{\max }(\log \varepsilon)=220$ (3.7), 230 (4.1), 304 (4.3) nm; IR (KBr pellet): $v=3391,2944$, 2365, 2339, 1613, 1600, 1468, 1458, 1437, 1421, 1339, 1292, 1224, 1208, 1156,1116, 1070, 1054, 986, 861, 802, 758, 698, 641, 597, 527, $461 \mathrm{~cm}^{-1} ;{ }^{1} \mathrm{H}$ NMR and ${ }^{13} \mathrm{C}$ NMR ([Table 2]); HR-ESI-MS: $\mathrm{m} / \mathrm{z}=327.08301[\mathrm{M}+\mathrm{Na}]^{+}$(calcd. for $\mathrm{C}_{16} \mathrm{H}_{16} \mathrm{O}_{6} \mathrm{Na}^{+} ; 327.08391$ ).

\section{X-ray structure determination}

A single crystal of 2 was selected under paratone oil and transferred on a SuperNova, single source at offset, Eos diffractometer. The crystal was kept at 100.0(1) K during data collection. Using Olex2 [26], the structure was solved with ShelXS-97 and refined with the ShelXL-97 [27] refinement package using least squares minimization. The sum formula is $\mathrm{C}_{16} \mathrm{H}_{16} \mathrm{O}_{6} \cdot \mathrm{H}_{2} \mathrm{O}, \mathrm{M}=322.30 \mathrm{~g} / \mathrm{mol}$, triclinic, space group Pī (no. 2), $\mathrm{a}=7.2955$ (3) $\AA$, b = 9.9851 (4) $\AA, c=11.0641(4) \AA, \alpha=109.954(4)^{\circ}, \beta=94.051(3)^{\circ}, \gamma=91.808(3)^{\circ}, V=754.37(5) \AA^{3}$, $Z=2, \mu($ MoK $\alpha)=0.112 \mathrm{~mm}^{-1}$, Dcalc $=1.419 \mathrm{~g} / \mathrm{cm}^{3}, 15039$ reflections measured $\left(5.6^{\circ} \leq 2 \Theta\right.$ $\left.\leq 60.0^{\circ}\right), 4403$ unique $\left(R_{\text {int }}=0.0204\right)$, which were used in all calculations. The final $R_{1}$ was $0.0393(I>2 \sigma(I))$ and $W_{2}$ was 0.1137 (all data). CCDC 1016089 contains the supplementary crystallographic data for this paper. These data can be obtained free of charge from The Cambridge Crystallographic Data Centre via www.ccdc.cam.ac.uk/data_request/cif.

Antibacterial activity

Compounds 1-4 and 6 were tested for their antimicrobial activity against six bacteria: three gram-positive bacteria (Staphylococcus aureus ATCC 29213, Enterococcus faecalis ATCC 29212, Bacillus cereus ATCC 14579) and three gram-negative bacteria (Escherichia coli ATCC 25922, Pseudomonas aeruginosa ATCC 27853 and Salmonella typhimurium ATCC 14028). This activity was evaluated by determining the MIC using a rapid broth microdilution technique with p-iodonitrotetrazolium violet (INT) as the growth indicator as described by Eloff [28]. Gentamicin (50 mg/mL, Virbac) was used as a reference antibiotic drug. The samples were serially diluted to provide a final concentration range of 256 to $2 \mu \mathrm{g} / \mathrm{mL}$ and 4 to 0.03 for gentamycin.

Antioxidant activity

$D P P H$ and ABTS assays: The DPPH and ABTS radical scavenging activities were determined using the modifications of the 96-well microtiter plate method described by Brand-Williams et al. [29] and Re et al. [30], respectively. 2,5,7,8-Tetramethylchroman carboxylic acid (trolox; $97 \%$ purity) and L-ascorbic acid (99\% purity; purchased from Sigma-Aldrich) were used as positive controls, methanol was used as a negative control, and samples without 
DPPH or $\mathrm{ABTS}^{\circ+}$ solution were used as blanks. Results are expressed as percentage reduction of the initial DPPH or $\mathrm{ABTS}^{\circ+}$ absorption in relation to the control. The $\mathrm{IC}_{50}$ values were calculated from the graph plotted as inhibition percentage against the concentration.

Ferric reducing antioxidant power (FRAP) assay: The FRAP assay was carried out according to the procedure of Benzie and Strain [31] with slight modifications. Briefly, the FRAP reagent was prepared from acetate buffer ( $\mathrm{pH}$ 3.6), $10 \mathrm{mM}$ TPTZ solution in $40 \mathrm{mM} \mathrm{HCl}$, and $20 \mathrm{mM}$ iron (III) chloride solution in proportions of $10: 1: 1(\mathrm{v} / \mathrm{v})$, respectively. The FRAP reagent was prepared fresh daily and was warmed to $37^{\circ} \mathrm{C}$ in a water bath prior to use. Fifty $\mu \mathrm{L}$ of sample were added to $1.5 \mathrm{~mL}$ of the FRAP reagent. The absorbance of the reaction mixture was then recorded at $593 \mathrm{~nm}$ after $4 \mathrm{~min}$. The standard curve was constructed using $\mathrm{FeSO}_{4}$ solution (0.1-2 mM), and the results are expressed as $\mu \mathrm{g} \mathrm{FeSO} / \mathrm{g}$ of the compound. All the measurements were taken in triplicate, and the mean values were calculated.

\section{Acknowledgements}

A. M. L. would like to thank the Alexander von Humboldt-Stiftung for the award of a Georg Forster Fellowship for Experienced Researchers (ID N¹137675). H. F. would like to acknowledge the German Academic Exchange Service (DAAD, Referat 412; PKZ A/12/904 859) for the fellowship at Bielefeld University (Germany). This paper is also dedicated to the memory of Professor David Lontsi who passed away on December 22, 2008.

\section{Conflict of Interest}

The authors declare no conflict of interest.

\section{References}

1 Bennett GJ, Lee H. Xanthones from the Guttiferaceae. Phytochemistry 1989; 28: 967-998

2 Waterman PG, Hussain RA. Systematic significance of xanthones, benzophenones and biflavonoids in Garcinia. Biochem Syst Ecol 1983; 11: 21-28

3 Nguyen LH, Harrison $\sqcup$. Xanthones and triterpenoids from the bark of Garcinia vilersiana. Phytochemistry 2000; 53: 111-114

4 Permana D, Lajis NH, Mackeen MM, Ali AM, Aimi N, Kitajima M, Takayama H. Isolation and bioactivities of constituents of the roots of Garcinia atroviridis. J Nat Prod 2001; 64: 976-979 
5 Suksamrarn S, Suwannapoch N, Phakhodee W, Thanuhiranlert J, Ratananukul P, Chimnoi $\mathrm{N}$, Suksamrarn A. Antimycobacterial activity of prenylated xanthones from the fruits of Garcinia mangostana. Chem Pharm Bull 2003; 51: 857-859

6 Hay AE, Hélesbeux JJH, Duval O, Labaïed M, Grellier P, Richomme P. Antimalarial xanthones from Calophyllum caledonicum and Garcinia vieillardii. Life Sci 2004; 75: 30773085

7 Shadid KA, Shaari K, Abas F, Israf DA, Hamzah AS, Syakroni N, Saha K, Lajis NH. Cytotoxic caged-polyprenylated xanthonoids and a xanthone from Garcinia cantleyana.

Phytochemistry 2007; 68: 2537-2544

8 Wu CC, Lu YH, Wei BL, Yang SC, Won SJ, Lin CN. Phloroglucinols with prooxidant activity from Garcinia subelliptica. J Nat Prod 2008; 71: 246-250

9 Yu L, Zhao M, Yang B, Bai W. Immunomodulatory and anticancer activities of phenolics from Garcinia mangostana fruit pericarp. Food Chem 2009; 116: 969-973

10 Fouotsa H, Meli Lannang A, Mbazoa CD, Rasheed S, Bishnu PM, Zulfiqar A, Krishna PD, Kengfack AE, Farzana S, Muhammad IC, Sewald N. Xanthones inhibitors of $\alpha$-glucosidase and glycation from Garcinia nobilis. Phytochem Lett 2012; 5: 236-239

11 Gustafson KR, Blunt JW, Munro MHG, Fuller RW, McKee TC, Cardellina 2nd JH, McMahon JB, Cragg GM, Boyd MR. The guttiferones, HIV-inhibitory benzophenones from Symphonia globulifera, Garcinia livingstonei, Garcinia ovalifolia and Clusia rosea. Tetrahedron 1992; 48: 10093-10102

12 Ampofo AS, Waterman GP. Xanthones from three Garcinia species. Phytochemistry 1986; 25: 2351-2355

13 Berhaut J. Flore illustrée du Sénégal. Dakar: Ministère du Développement Rural et de L'Hydraulique, Direction des Eaux et Forêts; 1975: 89-90

14 Bouquet A. Féticheurs et Médecines Traditionnelles du Congo (Brazzaville). Paris: O.R.S.T.O.M.; 1969: 133

15 Meli Lannang A, Komguem J, Ngounou NF, Tangmouo JG, Lontsi D, Ajaz A, lqbal MC, Beiban LS. Atta-ur-Rahman. Antioxidant benzophenones and xanthones from the root bark of Garcinia smeathmannii. Bull Chem Soc Ethiop 2006; 20: 247-252

16 Komguem J, Meli Lannang A, Manfouo NR, Lontsi D, Ngounou NF, Kuete V, Kamdem WH, Tane P, Ngadjui TB, Sondengam LB, Connelly DJ. Xanthones from Garcinia smeathmannii (Oliver) and their antimicrobial activity. Phytochemistry 2005; 66: 1713-1717

17 Kuete V, Komguem J, Penlap Beng V, Meli Lannang A, Tangmouo JG, Etoa F-X, Lontsi D. Antimicrobial components of the methanolic extract from the stem bark of Garcinia smeathmannii Oliver (Clusiaceae). S Afr J Bot 2007; 73: 347-354 
18 Wu YP, Zhao W, Xia ZY, Kong GH, Lu XP, Hu QF, Gao XM. Three novel xanthones from Garcinia paucinervis and their anti-TMV activity. Molecules 2013; 18: 9663-9669

19 Satish K, Kanwal R, Pratibha K. Flavones and acridones from Atalantia wightii. Indian J Chem 2009; 48: 291-294

20 Hiroyuki M, Emi T, Mitsuaki K, Yoshiyasu F. Three xanthones from Garcinia subelliptica. Phytochemistry 1996; 41: 629-633

21 Nkengfack EA, Mkounga P, Fomum TZ, Meyer M, Bodo B. Globulixanthones A and B, two new cytotoxic xanthones with isoprenoid groups from the root bark of Symphonia globulifera. J Nat Prod 2002; 65: 734-736

22 Ricaldez FT, Vega GRA. Phytochemical study of Rheedia gardneriana. Rev Boliv Quim 2000; 17: 9-14

23 Nguyen LH, Venkatraman G, Sim KY, Harrison L. Xanthones and benzophenones from Garcinia griffithii and Garcinia mangostana. Phytochemistry 2005; 66: 1718-1723

24 Pinto MMM, Sousa ME, Nascimento MSJ. Xanthone derivatives: new insights in biological activities. Curr Med Chem 2005; 12: 2517-2538

25 Chen Y, Fan H, Yang GZ, Jiang Y, Zhong FF, He HW. Prenylated xanthones from the bark of Garcinia xanthochymus and their 1,1-diphenyl-2-picrylhydrazyl (DPPH) radical scavenging activities. Molecules 2010; 15: 7438-7449

26 Dolomanov OV, Bourhis L, Gildea RJ, Howard JAK, Puschmann H. OLEX2: a complete structure solution, refinement and analysis program. J Appl Cryst 2009; 42: 339-341

27 Sheldrick GM. A short history of SHELX . Acta Cryst 2008; 64: 112-122

28 Eloff JN. A sensitive and quick microplate method to determine the minimal inhibitory concentration of plant extracts for bacteria. Planta Med 1998; 64: 711-713

29 Brand-Williams W, Cuvelier ME, Berset C. Use of a free radical method to evaluate antioxidant activity. LWT Food Sci Technol 1995; 28: 25-30

30 Re R, Pellegrini N, Proteggente A, Pannala A, Yang M, Rice-Evans C. Antioxidant activity applying an improved ABTS radical cation decolorization assay. Free Radic Biol Med 1999; 26: $1231-1237$

31 Benzie IF, Strain JJ. The ferric reducing ability of plasma (FRAP) as a measure of "antioxidant power": the FRAP assay. Anal Biochem 1996; 239: 70-76 


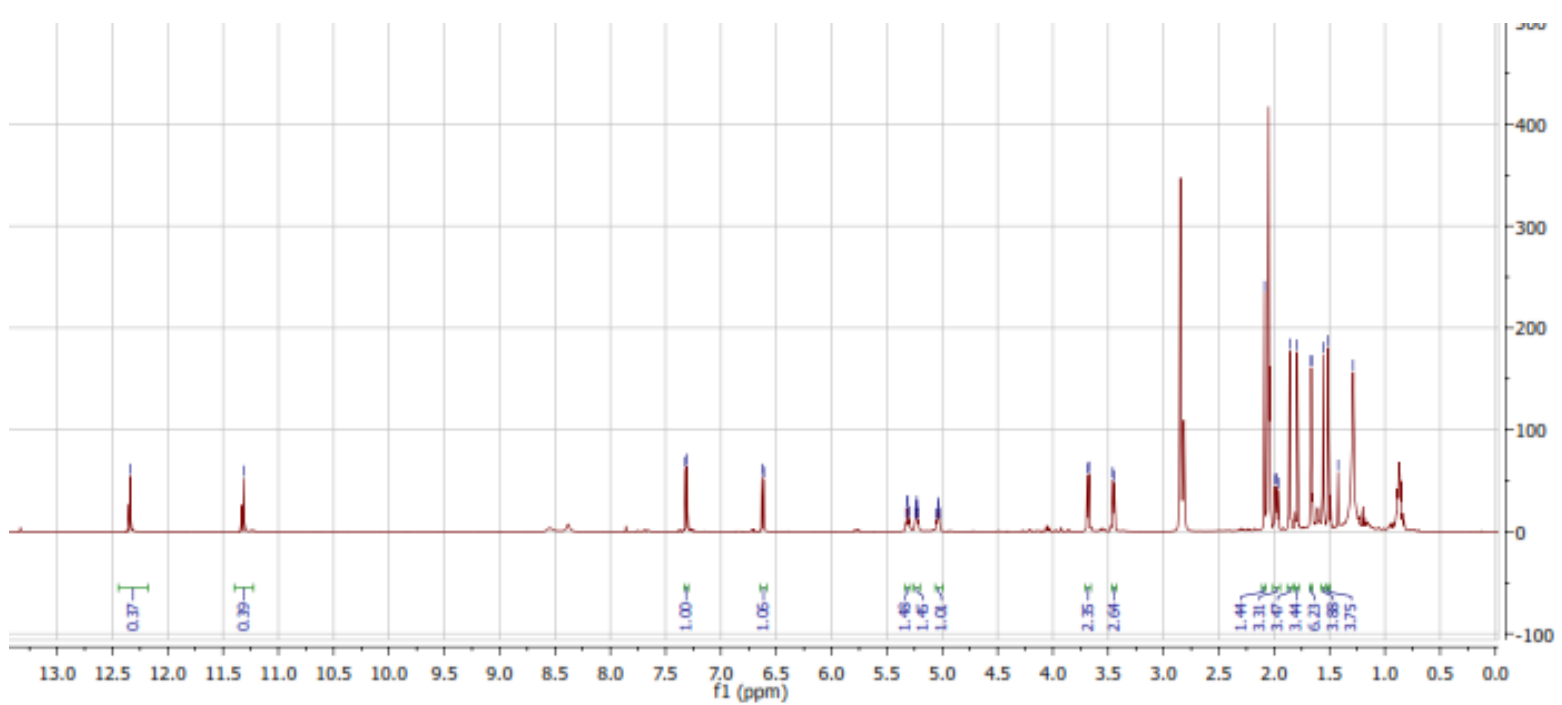

${ }^{1} \mathrm{H}$ NMR of compound 1 .

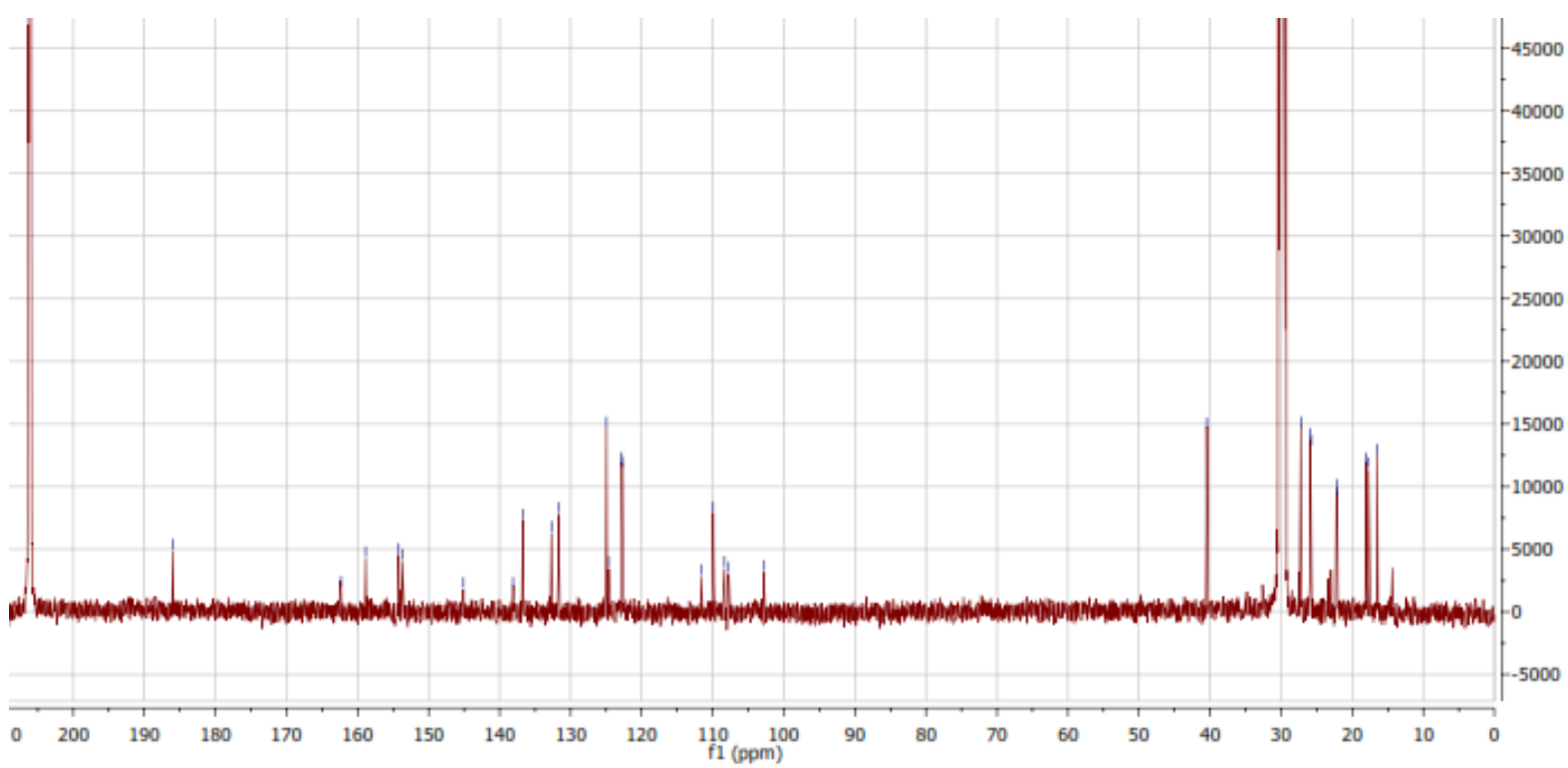

${ }^{13} \mathrm{C}$ NMR of compound 1. 


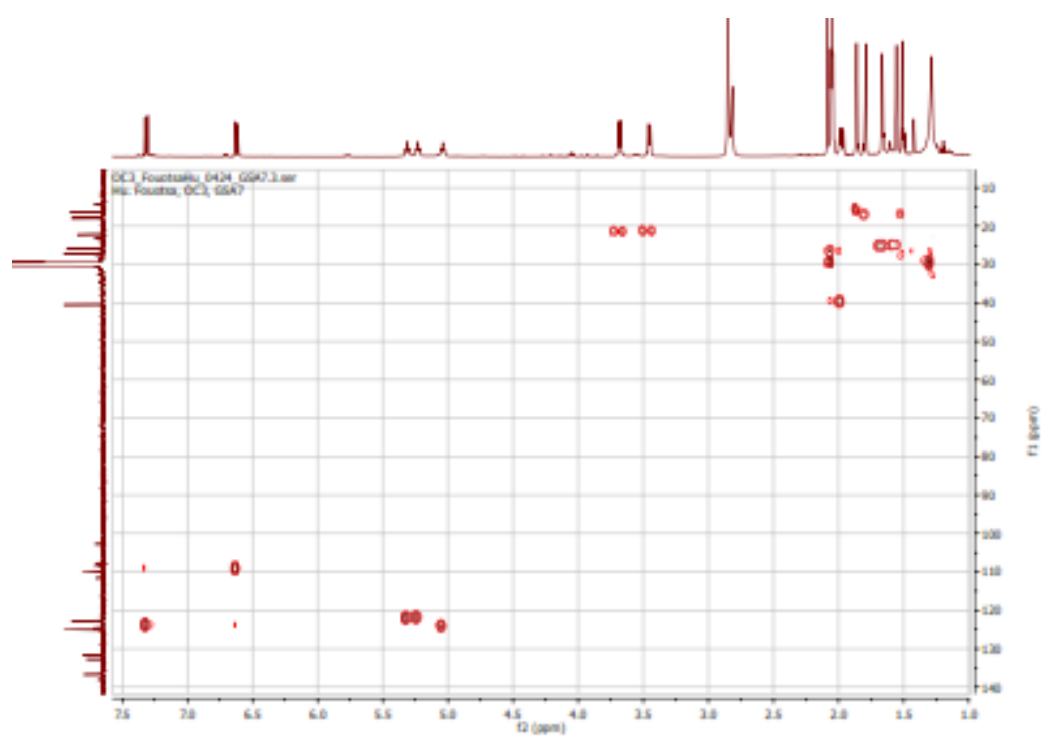

HMQC NMR of compound 1.

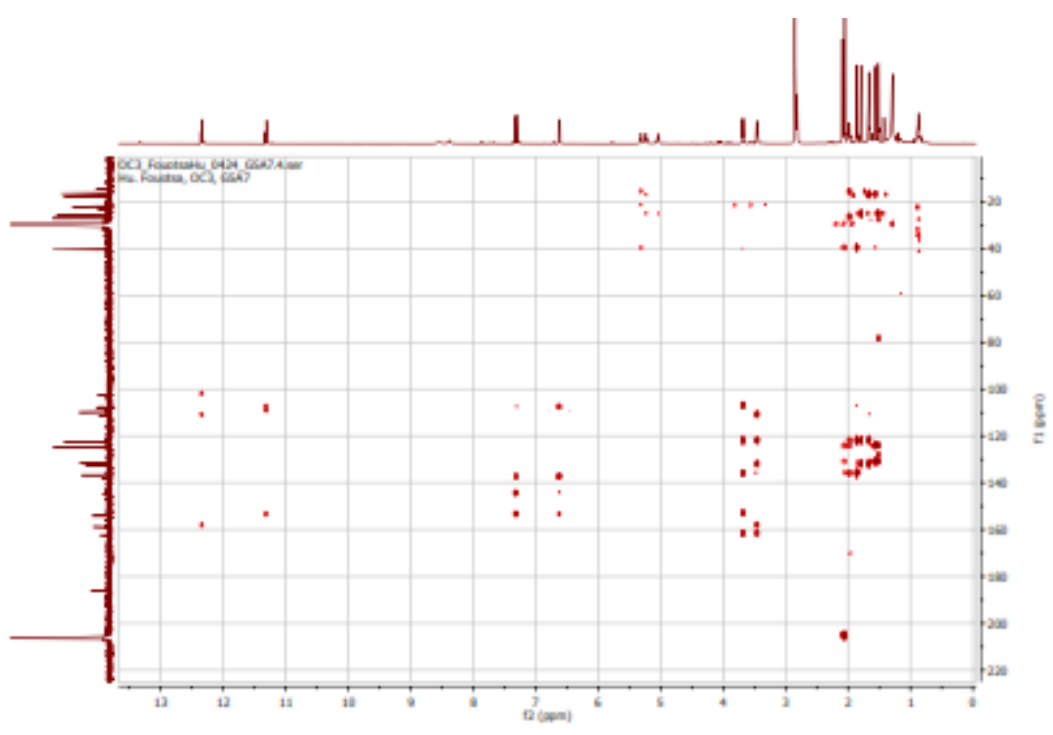

HMBC NMR of compound 1.

14 


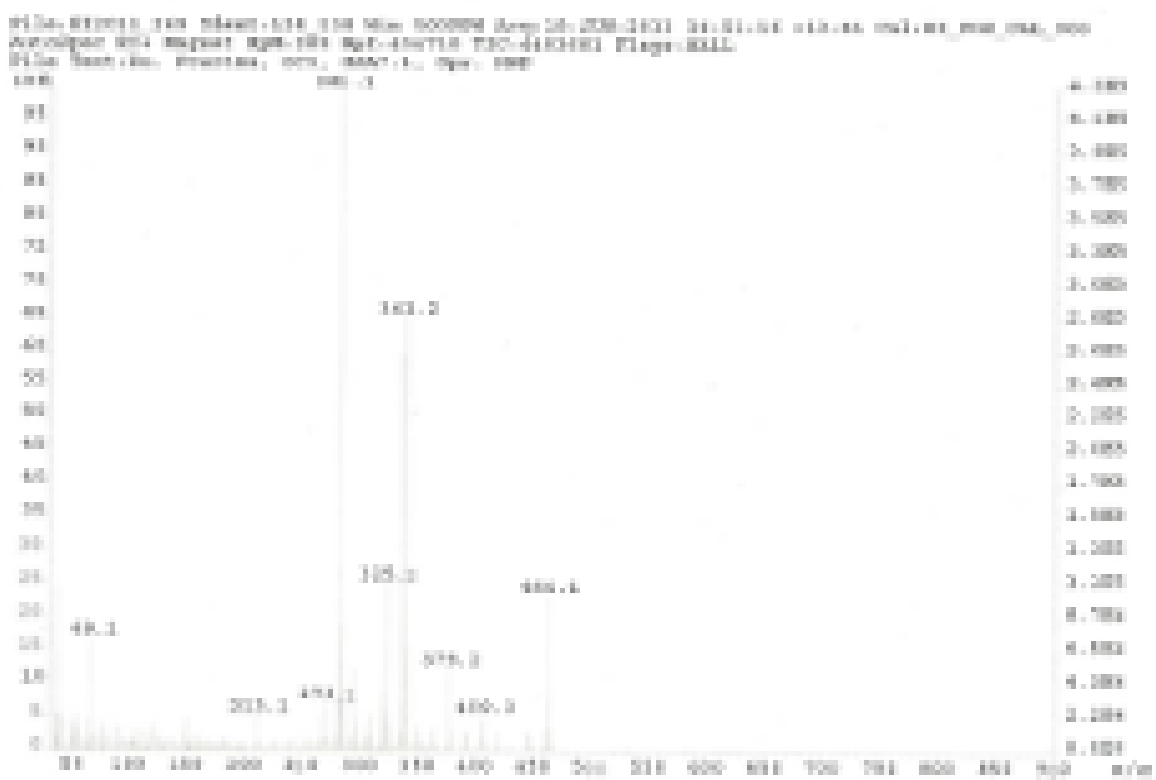

El mass of compound 1 . 


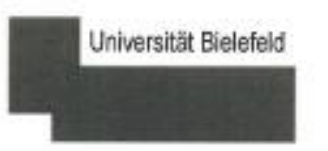

Fakultăt fur Chemie - Organische Chemie I Abteilung Massenspektromotrio F02-217

Universititsotrabe 25
33501 Bielefeld

I $0521-106-2108$

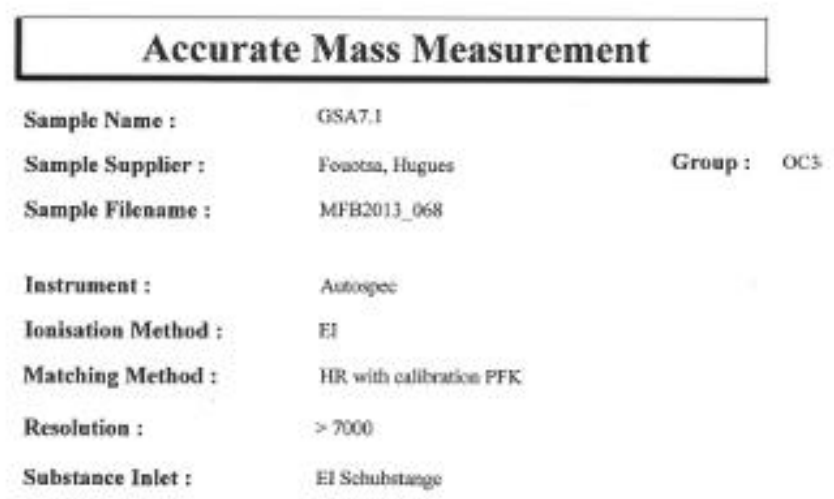

\begin{tabular}{|c|c|c|c|}
\hline Measured PFK Mass(es) : & $466,972 \mathrm{RS}$ & & \\
\hline Measured Ion Mass(es) : & 464.21920 & Deviation [mmu] : & 0,14 \\
\hline Calculated Ion Mass(es) : & 464,21934 & Deviation [ppm] : & 0,30 \\
\hline Potential Molecular Formul & $\mathrm{C} 28 \mathrm{H} 3206+$ & & \\
\hline
\end{tabular}

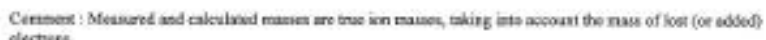

Bielofeld 24062013

HR-El mass of compound 1.

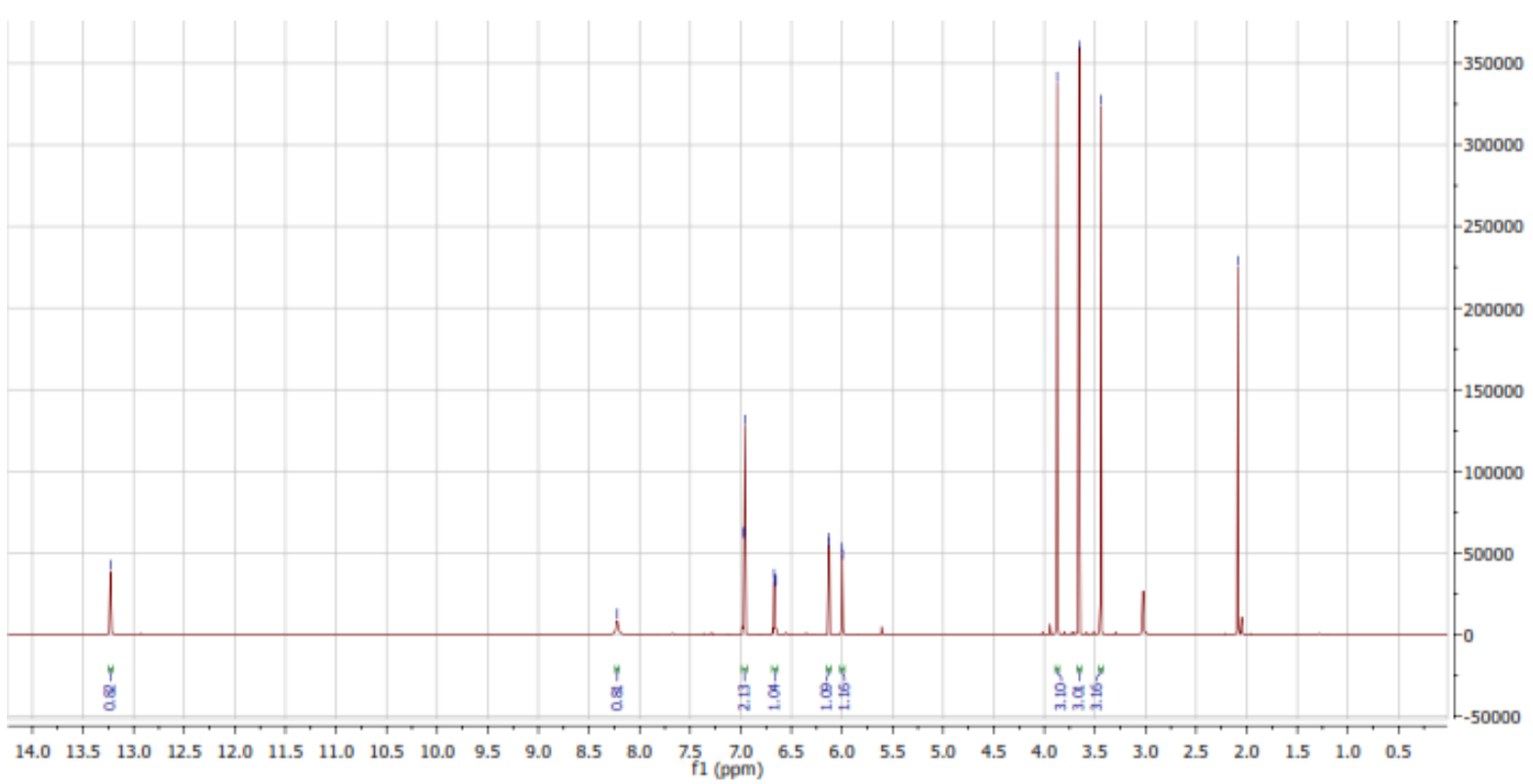

${ }^{1} \mathrm{H}$ NMR of compound 2. 


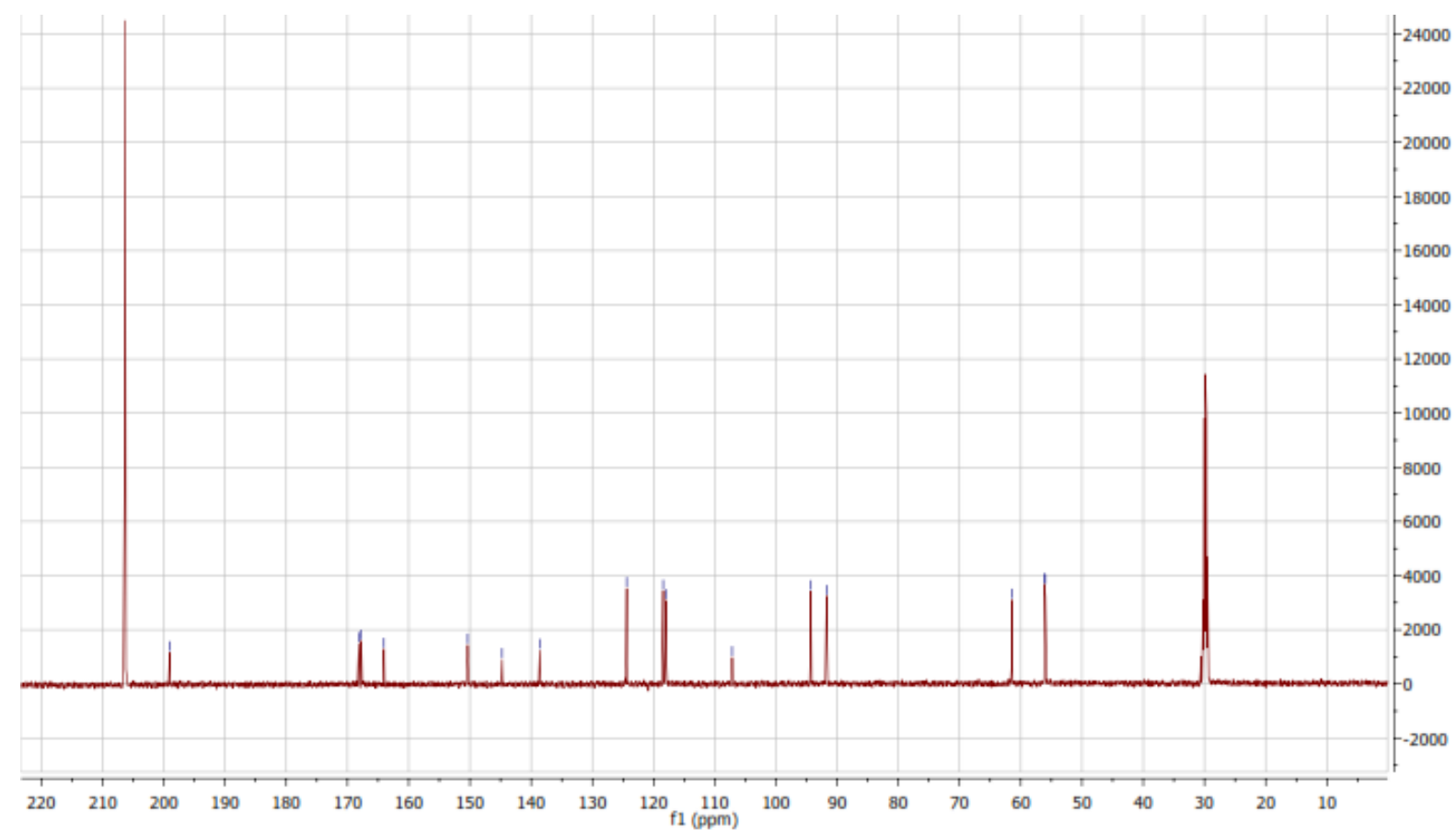

${ }^{13} \mathrm{C}$ NMR of compound 2.

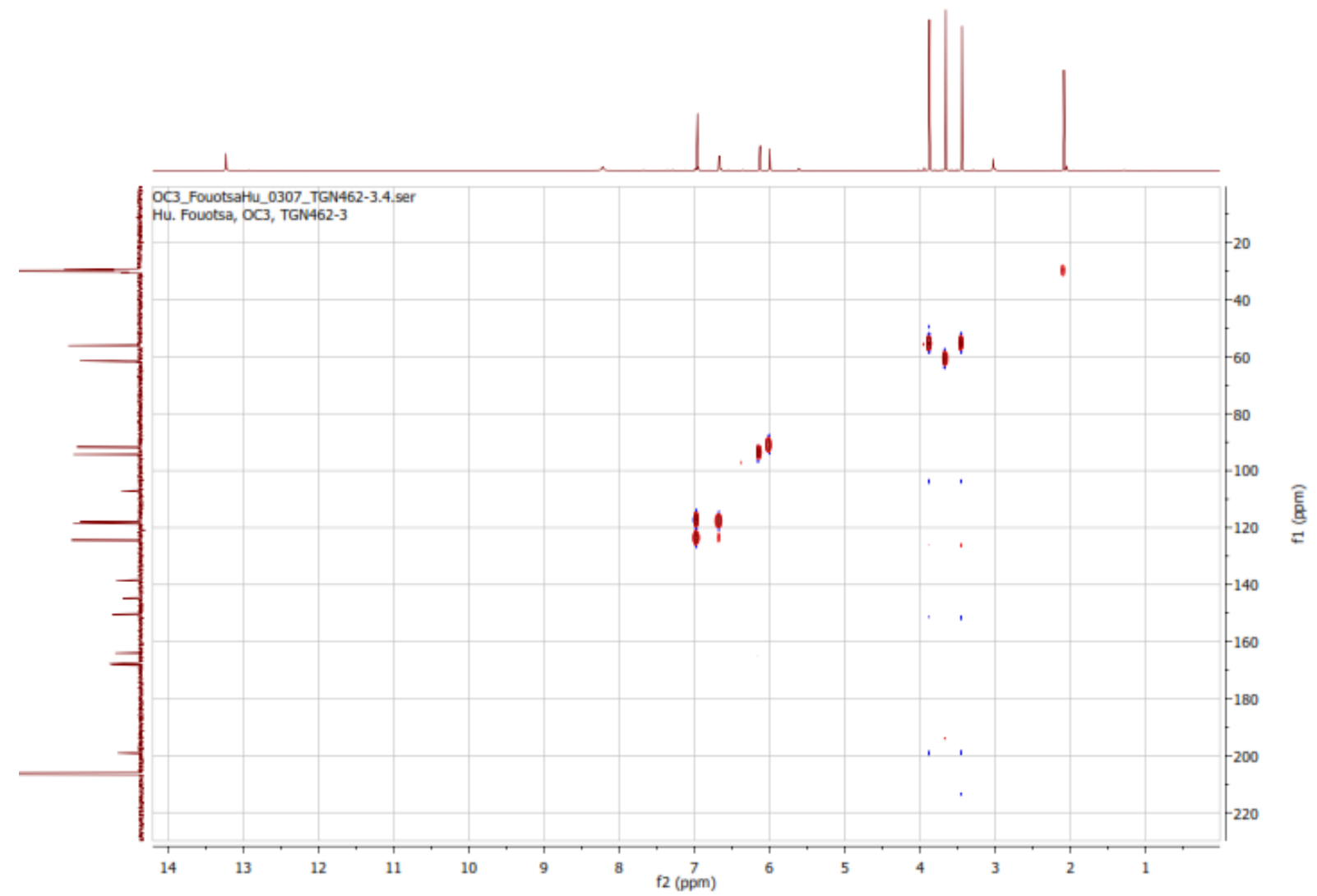

HMQC NMR of compound 2. 


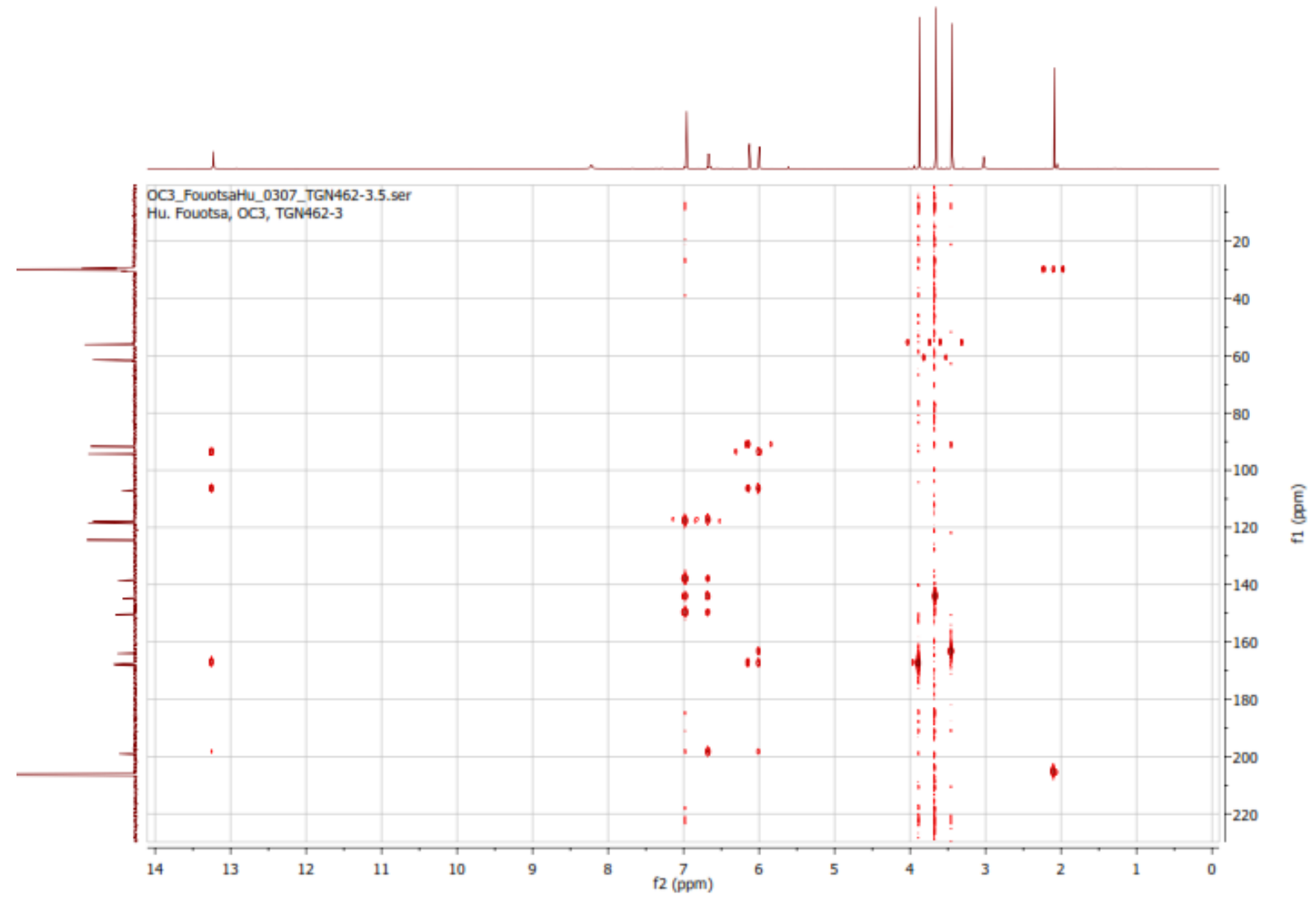

HMBC NMR of compound 2 .

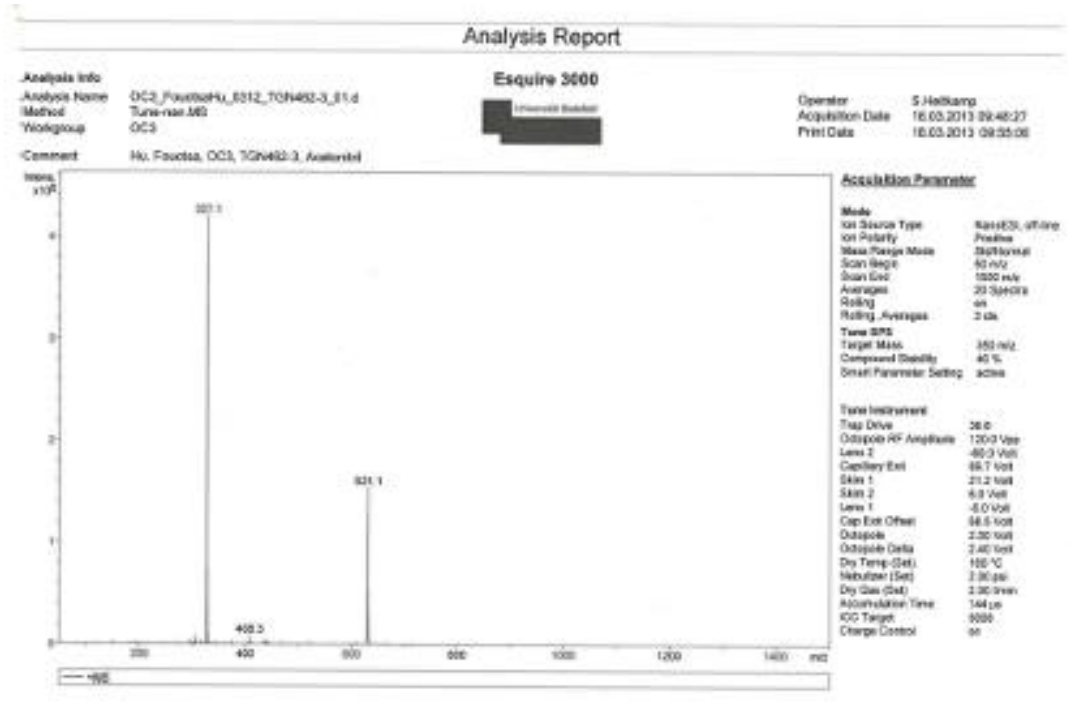

ESI mass of compound 2. 
Q 0521 - $106-2108$

\section{Accurate Mass Measurement}

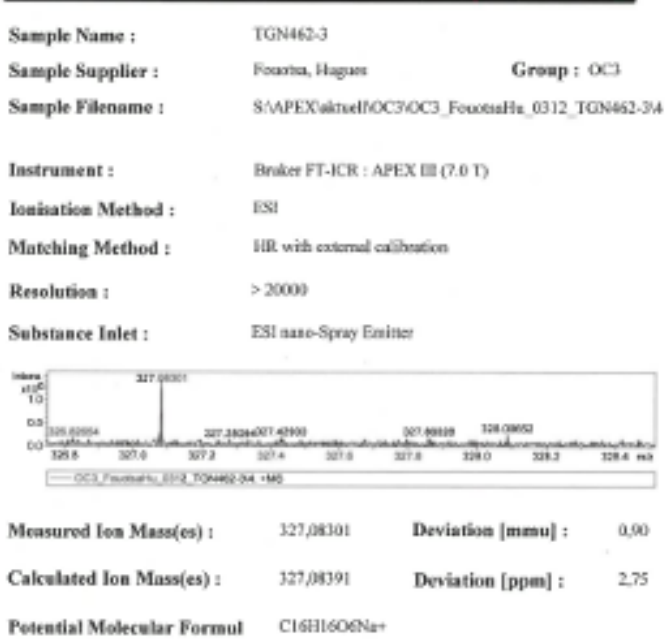

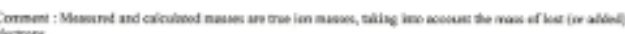

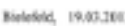

HR-ESI mass of compound 2. 